\title{
Choreatic Side Effects of Deep Brain Stimulation of the Anteromedial Subthalamic Nucleus for Treatment- Resistant Obsessive-Compulsive disorder
}

Citation for published version (APA):

Mulders, A. E. P., Leentjens, A. F. G., Schruers, K., Duits, A., Ackermans, L., \& Temel, Y. (2017).

Choreatic Side Effects of Deep Brain Stimulation of the Anteromedial Subthalamic Nucleus for TreatmentResistant Obsessive-Compulsive disorder. World Neurosurgery, 104, 1048.e9-1048.313. https://doi.org/10.1016/j.wneu.2017.05.067

Document status and date:

Published: 01/08/2017

DOI:

10.1016/j.wneu.2017.05.067

Document Version:

Publisher's PDF, also known as Version of record

Document license:

Taverne

Please check the document version of this publication:

- A submitted manuscript is the version of the article upon submission and before peer-review. There can be important differences between the submitted version and the official published version of record.

People interested in the research are advised to contact the author for the final version of the publication, or visit the DOI to the publisher's website.

- The final author version and the galley proof are versions of the publication after peer review.

- The final published version features the final layout of the paper including the volume, issue and page numbers.

Link to publication

\footnotetext{
General rights rights.

- You may freely distribute the URL identifying the publication in the public portal. please follow below link for the End User Agreement:

www.umlib.nl/taverne-license

Take down policy

If you believe that this document breaches copyright please contact us at:

repository@maastrichtuniversity.nl

providing details and we will investigate your claim.
}

Copyright and moral rights for the publications made accessible in the public portal are retained by the authors and/or other copyright owners and it is a condition of accessing publications that users recognise and abide by the legal requirements associated with these

- Users may download and print one copy of any publication from the public portal for the purpose of private study or research.

- You may not further distribute the material or use it for any profit-making activity or commercial gain

If the publication is distributed under the terms of Article 25fa of the Dutch Copyright Act, indicated by the "Taverne" license above, 


\title{
Choreatic Side Effects of Deep Brain Stimulation of the Anteromedial Subthalamic Nucleus for Treatment-Resistant Obsessive-Compulsive disorder
}

\author{
Anne E.P. Mulders ${ }^{1-3}$, Albert F.G. Leentjens ${ }^{2}$, Koen Schruers ${ }^{2}$, Annelien Duits $^{2}$, Linda Ackermans $^{1}$, Yasin Temel $^{1,3,4}$
}

\section{Key words}

- Deep brain stimulation

- Obsessive-compulsive disorder

- Side effects

- Subthalamic nucleus

- Ventral capsule/ventral striatum

\section{Abbreviations and Acronyms \\ DA: Dopamine \\ DBS: Deep brain stimulation \\ MRI: Magnetic resonance imaging \\ NAc: Nucleus accumbens \\ OCD: Obsessive-compulsive disorder \\ PD: Parkinson disease \\ STN: Subthalamic nucleus \\ vC/VS: Ventral capsule/ventral striatum \\ Y-B0cs: Yale-Brown Obsessive Compulsive Scale}

From the Departments of ${ }^{\mathbf{1}}$ Neurosurgery, ${ }^{2}$ Psychiatry and Neuropsychology, ${ }^{\mathbf{3}}$ Neuroscience, Maastricht University Medical Center, Maastricht; and ${ }^{4}$ Donders Institute for Brain, Cognition and Behaviour, Department of Neurosurgery, Radboud University Medical Center, Nijmegen, the Netherlands

To whom correspondence should be addressed: Yasin Temel, M.D., Ph.D.

[E-mail:y.temel@maastrichtuniversity.nl]

A.E.P.M. collected the clinical data and wrote the first draft of the manuscript. Together with A.D., she applied the Y-BOCS. Y.T. and L.A. performed the DBS surgeries. K.S. was involved in the preoperative screening. A.F.G.L. was the treating physician of the patient and as such involved in preoperative screening, clinical treatment, outpatient follow-up, and DBS programming. All authors were part of the multidisciplinary team involved in the treatment of the patient. All authors gave critical comments on the first and subsequent drafts of the paper and approved the final manuscript.

Citation: World Neurosurg. (2017) 104:1048.e9-1048.e13. http://dx.doi.org/10.1016/j.wneu.2017.05.067

Journal homepage: www.WORLDNEUROSURGERY.org

Available online: www.sciencedirect.com

1878-8750/\$ - see front matter (c) 2017 Elsevier Inc. All rights reserved.

\section{INTRODUCTION}

Obsessive-compulsive disorder (OCD) is characterized by the repeated occurrence of upsetting obsessions or compulsions that are related to substantial dysfunction in multiple domains of life. ${ }^{\mathrm{I}}$ Despite intensive psychotherapeutic and pharmacologic treatments, a significant proportion of

BACKGROUND: Patients with treatment-resistant obsessive-compulsive disorder (OCD) are potential candidates for deep brain stimulation (DBS). The anteromedial subthalamic nucleus (STN) is among the most commonly used targets for DBS in OCD.

CASE DESCRIPTION: We present a patient with a 30-year history of treatment-resistant OCD who underwent anteromedial STN-DBS. Despite a clear mood-enhancing effect, stimulation caused motor side effects, including bilateral hyperkinesia, dyskinesias, and sudden large amplitude choreatic movements of arms and legs when stimulating at voltages greater than approximately 1.5 V. DBS at lower amplitudes and at other contact points failed to result in a significant reduction of obsessions and compulsions without inducing motor side effects. Because of this limitation in programming options, we decided to reoperate and target the ventral capsule/ventral striatum (VC/VS), which resulted in a substantial reduction in key obsessive and compulsive symptoms without serious side effects.

CONCLUSIONS: Choreatic movements and hemiballismus have previously been linked to STN dysfunction and have been incidentally reported as side effects of DBS of the dorsolateral STN in Parkinson disease (PD). However, in PD, these side effects were usually transient, and they rarely interfered with DBS programming. In our patient, the motor side effects were persistent, and they made optimal DBS programming impossible. To our knowledge, such severe and persistent motor side effects have not been described previously for anteromedial STN-DBS.

patients fail to respond to therapy. Patients with treatment-resistant OCD are potential candidates for deep brain stimulation (DBS). ${ }^{3}$ The ventral capsule/ventral striatum (VC/VS), the nucleus accumbens (NAc), and the anteromedial limbic portion of the subthalamic nucleus (STN) are among the most common DBS targets for OCD. ${ }^{\mathrm{I}}$ The aim of DBS is to tailor the treatment on a patient-specific basis to deliver optimal therapeutic effects while avoiding stimulation-associated side effects. Minor complications have been reported, of which the majority were time limited and reversed by adjusting the stimulation settings. ${ }^{\mathrm{I}, 4,5}$ We present significant stimulation-associated side effects following DBS of the anteromedial STN that have not been described previously and that required reimplantation to an alternative target-the VC/VS.

\section{CASE DESCRIPTION}

A 47-year old woman with refractory OCD was referred to our hospital for DBS. The patient had OCD since the age of $\mathrm{I}_{5}$, and it was characterized clinically by intrusive thoughts about dirt, accompanied with excessive cleaning, washing, and checking compulsions that occupied the entire day. In addition, the patient experienced a lowered mood, anhedonia, and occasional panic attacks, though failing to meet the 
Table 1. Patient Characteristics and Stimulation Settings

\begin{tabular}{|c|c|c|}
\hline \multicolumn{3}{|l|}{$\begin{array}{l}\text { Medication Used } \\
\text { Before Surgery* }\end{array}$} \\
\hline & Clomipramine & Haloperidol \\
\hline & Sertraline & Oxazepam \\
\hline & Citalopram & Fluoxetine \\
\hline & Mirtazapine & Venlafaxine \\
\hline & Paroxetine & Aripiprazol \\
\hline Target Coordinates $\dagger$ & STN & VC/VS \\
\hline$x$ & 10 & 7 \\
\hline Y & 0 & $12.8(\mathrm{~L}) / 12.7(\mathrm{R})$ \\
\hline Z & -4 & -3 \\
\hline Stimulator Settings & Left & Right \\
\hline \multirow[t]{6}{*}{ Tested STN DBS settings $\ddagger$} & 1- $\mathrm{C}+, 90 \mu \mathrm{s}, 130 \mathrm{~Hz}$ & 9- $\mathrm{C}+, 90 \mu \mathrm{s}, 130 \mathrm{~Hz}$ \\
\hline & 2- $\mathrm{C}+, 90 \mu \mathrm{s}, 130 \mathrm{~Hz}$ & 10- C+, $90 \mu \mathrm{s}, 130 \mathrm{~Hz}$ \\
\hline & 3- $\mathrm{C}+, 90 \mu \mathrm{s}, 130 \mathrm{~Hz}$ & 11- C+, $90 \mu \mathrm{s}, 130 \mathrm{~Hz}$ \\
\hline & 1- $2+, 90 \mu \mathrm{s}, 130 \mathrm{~Hz}$ & 9- $10+, 90 \mu \mathrm{s}, 130 \mathrm{~Hz}$ \\
\hline & 2- $\mathrm{C}+, 90 \mu \mathrm{s}, 130 \mathrm{~Hz}$ & 9- $\mathrm{C}+, 90 \mu \mathrm{s}, 130 \mathrm{~Hz}$ \\
\hline & $0-\mathrm{C}+, 90 \mu \mathrm{s}, 130 \mathrm{~Hz}$ & 8- C+ $90 \mu \mathrm{s}, 130 \mathrm{~Hz}$ \\
\hline Final VC/VS DBS settings & 1- 2- 3- C+, 3.4 V, $90 \mu \mathrm{s}, 130 \mathrm{~Hz}$ & 9- $10-11-\mathrm{C}+, 3.4 \mathrm{~V}, 90 \mu \mathrm{s}, 130 \mathrm{~Hz}$ \\
\hline \multicolumn{3}{|l|}{ Y-BOCS } \\
\hline Preoperative & & 34 \\
\hline $\begin{array}{l}\text { Postoperative } \\
\text { VC/VS } 1 \text { year FU }\end{array}$ & & 29 \\
\hline $\begin{array}{l}\text { Postoperative } \\
\text { VC/VS } 2 \text { year FU }\end{array}$ & & 17 \\
\hline \multicolumn{3}{|c|}{$\begin{array}{l}\text { STN, subthalamic nucleus; VC/VS = ventral capsule/ventral striatum; DBS, deep brain stimulation; Y-BOCS, Yale-Brown } \\
\text { Obsessive Compulsive Scale; FU, follow-up. } \\
\text { *Medication used before surgery refers to all the different pharmacologic trials conducted since the patient was first } \\
\text { treated until the first surgery. Adequate doses of these drugs were maintained for at least } 12 \text { weeks. } \\
\text { †istance from midanterior/posterior commissure in millimeters. } \\
\ddagger \text { Voltages were slowly increased with every setting. Dyskinesias occurred at voltages between } 1.5 \text { and } 2.1 \mathrm{~V} \text {. }\end{array}$} \\
\hline
\end{tabular}

criteria for major depressive disorder or any specific anxiety disorder. The patient also showed signs of borderline personality disorder. She had received several psychologic and pharmacologic treatments without any long-lasting relief on symptoms (Table 1). The patient was informed of the risks and benefits of DBS and underwent extensive multidisciplinary evaluation before surgery to ensure her suitability and compatibility for the treatment. The presurgery score on the Yale-Brown Obsessive Compulsive Scale (Y-BOCS) ${ }^{6}$ was 34 . was characterized by increased background activity, high-amplitude discharges, and burst-firing neurons. Postoperative imaging validated appropriate placement of the electrodes (Figure 1). See Table 1 for final target coordinates. Stimulation parameters were as follows: monopolar stimulation (left I-, right $9^{-}$, case + ), a pulse width of 90 microseconds, a frequency of $\mathrm{I} 30 \mathrm{~Hz}$, and an amplitude of $\mathrm{I} .5 \mathrm{~V}$ that had been slowly increased.

After activating the DBS therapy, the patient exhibited an immediate moodenhancing effect and relief in obsessions and compulsions. However, the patient developed unexpected compulsive behavior toward the operation wounds (scratching and itching), which has likely contributed to the development of a hardware infection. The infection was treated by removing the infected hardware (implanted pulse generator and cables) and antibiotic therapy. Two months later, new hardware was implanted and DBS therapy was reactivated. After this period, the mood-enhancing effect decreased, and the programming was limited by the fact that STN-DBS caused motor side effects upon stimulation greater than approximately $\mathrm{I} .5 \mathrm{~V}$. The motor side effects consisted of bilateral hyperkinesia and dyskinesias and sudden large amplitude choreatic movements of the arms and legs.

Following multiple DBS programming sessions (Table 1), including lowering the amplitude and using other contact points, no significant reduction of obsessions and compulsions could be achieved without inducing motor side effects. The patient also experienced mood swings. Despite continuation of pharmacotherapy and additional psychotherapeutic interventions, including intensive day treatment and behavioral therapy, the patient's quality of life remained poor, and the patient required further hospital admissions because of increased suicidal thoughts and an impulsively attempted suicide by autointoxication.

Because of the programming limitations and the fact that any therapeutic benefit was accompanied by intolerable motor side effects, we decided to reoperate and target the VC/VS region. In April 2014, when the patient was $5 \mathrm{I}$ years old, she underwent stereotactic reimplantation of the electrodes with the deepest electrode contact point in the area of the NAc (Model 3387 DBS lead; 


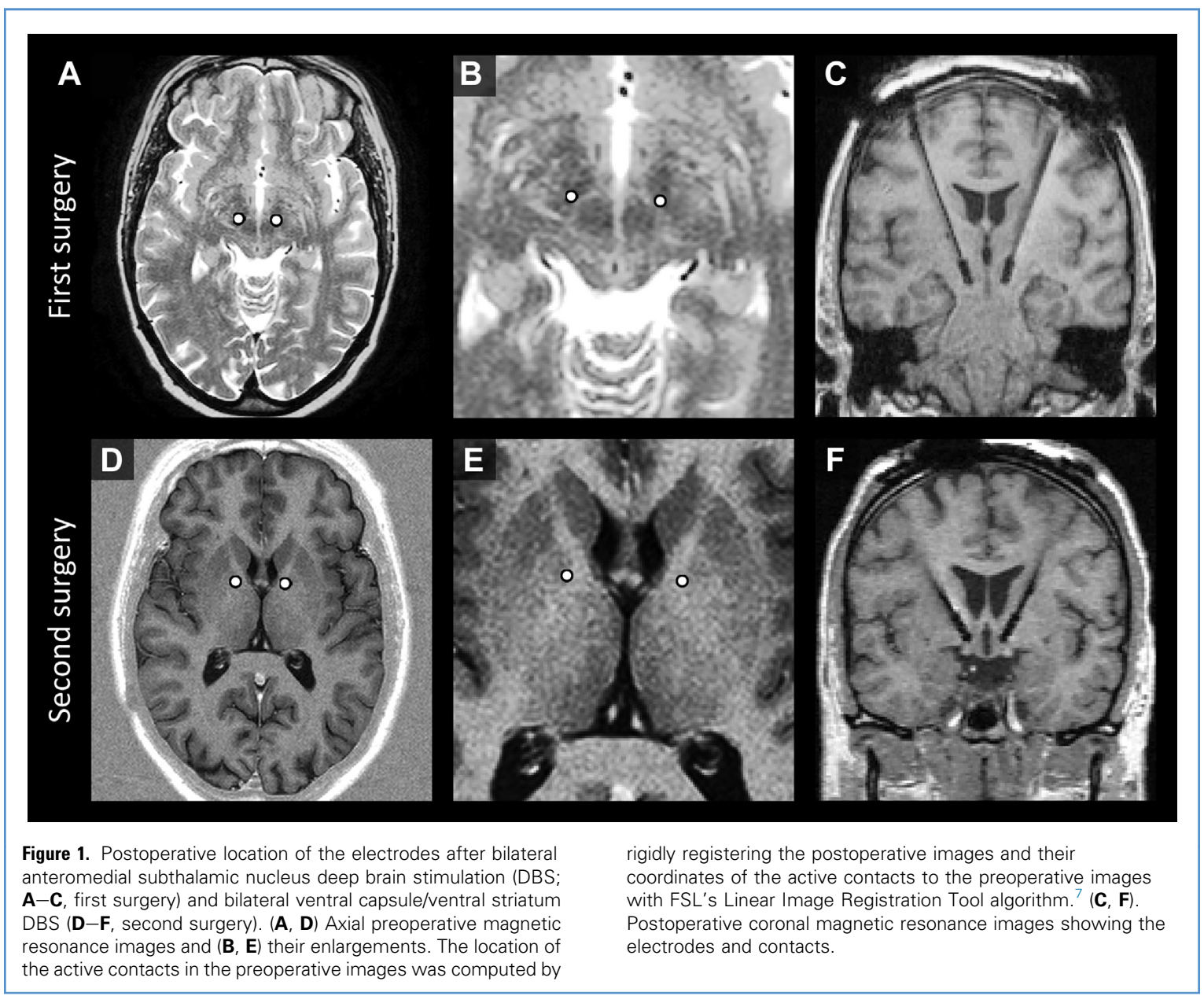

Medtronic). See Table 1 for final target coordinates. Postoperative imaging showed adequate placement of the electrodes at the planned target (Figure 1). After programming and additional psychotherapeutic therapy, therapeutic effect was achieved without inducing serious side effects. See Table 1 for stimulation parameters. One year postoperatively, the patient's Y-BOCS score was 29; 2 years postoperatively, the score was 17 , a reduction of $50 \%$ compared with baseline. At present, the patient reports a stabilization of daily life routines and improved quality of life.

\section{DISCUSSION}

This case illustrates that DBS of the anteromedial portion of the STN in OCD can cause persistent motor side effects that resemble chorea and ballism. Choreatic movements and (contralateral) hemiballismus have been associated with STN dysfunction $^{8}$ and have been reported following STN-DBS in Parkinson disease (PD), in which the dorsolateral sensorimotor portion of the STN is typically stimulated..$^{9-\mathrm{I} 2}$ Although these side effects are usually transient in $\mathrm{PD},{ }^{\mathrm{I} 2}$ they can make DBS programming difficult.9, ${ }^{\text {, Io }}$ Moreover, dyskinetic movements as side effects of STN-DBS in OCD have been reported in 2 patients in the French Stimulation dans le Trouble Obsessionnel Compulsif Study Group in the first month following stimulation. However, these movements resolved spontaneously or promptly after the adjustment of the stimulation settings. ${ }^{13}$ To our knowledge, such severe and persistent motor side effects that interfere with DBS programming have not been described previously for anteromedial STN-DBS.
The underlying mechanisms and pathophysiology of DBS-induced motor side effects are not well understood. Several disease-related risk factors have been identified for the emergence of such symptoms following STN-DBS in PD, including severe dyskinesias preoperatively and young onset PD. ${ }^{9}$ In addition, STN-DBS has been demonstrated to increase extracellular striatal dopamine (DA) metabolites in animal models of PD. ${ }^{\text {I4 }}$ Whereas PD is characterized by a progressive degeneration of nigral DA neurons, one can speculate that STN-DBS can result in an increase in striatal DA release and subsequently in hyperdopaminergic behaviors, such as dyskinesia in a patient with OCD and an intact DA system. This speculation is further supported by the finding that the increase in striatal DA metabolites following STN-DBS in naive rats was accompanied with transitory involuntary movements. 
Moreover, dyskinesias following STNDBS in PD have been associated with contact location within the dorsolateral portion of the STN. ${ }^{9, \text { II }}$ The idea that choreiform or ballistic movements result from stimulation or lesions of specific subdivisions of the STN is supported by a study in which a gammaaminobutyric acid receptor agonist was injected into the sensorimotor, associative, and limbic territories of the STN of green monkeys. ${ }^{16}$ Other than behavioral changes, no abnormal movements were observed after microinjection in the anteromedial portion of the STN, whereas injection into the dorsolateral and middle portions of the STN resulted in contralateral violent and rhythmic involuntary movements and leg ballismus, respectively. ${ }^{\mathrm{I}}$

Despite postoperative imaging showing adequate placement of the electrodes, there are individual differences regarding volume and position of the STN. ${ }^{17}$ In addition, a human clinical study using diffusionweighted tractography indicated a considerable degree of variation across individuals regarding the volume of structural subdivisions of the STN along the limbic, cognitive, and motor domains. ${ }^{\text {I8 }}$ In light of the individual differences in structural and functional anatomy of STN subdivisions, it is possible that in the case of the patient discussed, although the anteromedial portion of the STN was targeted, this part did in fact not constitute the nonmotor portion of the STN. Consequently, this may have led to the development of motor side effects, either directly by stimulation of the motor portion of the STN or indirectly by current spreading of contact points in close proximity to the motor portion of the STN. Importantly, while the concept of distinct functional subdivisions within the STN is popular in neuroanatomy research, ${ }^{\mathrm{Ig}-2 \mathrm{I}}$ it is still a matter of debate. In addition, others have suggested convergence ${ }^{22}$ or large overlap and interactions between these functional subdivisions. ${ }^{23,24}$

Future attempts to manage OCD with STN-DBS should focus in an individualized, patient-specific selection method that can determine the size and location of functional and structural subdivisions of the STN that can be achieved with, for example, preoperative diffusion-weighted imaging and tractography and functional MRI.

\section{CONCLUSION}

We have presented a case of persistent bilateral motor side effects in the lower extremities that limited programming possibilities in a patient who had undergone bilateral anteromedial STN-DBS for severe refractory OCD. Reimplantation of electrodes targeting the VC/VS with the deepest electrode contact point in the area of the NAc successfully overcame this limitation and resulted in adequate therapeutic response. Reimplantation to an alternative target should be considered if stimulation-associated side effects interfere with adequate programming of the DBS system, and this cannot be resolved by adjusting stimulation parameters.

\section{ACKNOWLEDGMENTS}

We are grateful to Dr. Birgit Plantinga with helping us with the MRI-related figure.

\section{REFERENCES}

I. Alonso P, Cuadras D, Gabriels L, Denys D, Goodman W, Greenberg BD, et al. Deep brain stimulation for obsessive-compulsive disorder: a meta-analysis of treatment outcome and predictors of response. PLoS One. 2015;I0: eoI3359I.

2. Temel Y, Hescham SA, Jahanshahi A, Janssen ML, Tan SK, van Overbeeke JJ, et al. Neuromodulation in psychiatric disorders. Int Rev Neurobiol. 2012; I07:283-3I4.

3. Mulders AE, Plantinga BR, Schruers K, Duits A, Janssen ML, Ackermans L, et al. Deep brain stimulation of the subthalamic nucleus in obsessive-compulsive disorder: neuroanatomical and pathophysiological considerations. Eur Neuropsychopharmacol. 2016;26: Igo9-IgIg.

4. Mangas M, Moreira R. Deep brain stimulation for obsessive-compulsive disorder: a literature review. J Obsessive-Compulsive Relat Disord. 2013;2: 39I-398.

5. Kohl S, Schonherr DM, Luigjes J, Denys D, Mueller UJ, Lenartz D, et al. Deep brain stimulation for treatment-refractory obsessive compulsive disorder: a systematic review. BMC Psychiatry. 20I4;I4:2I4

6. Goodman WK, Price LH, Rasmussen SA, Mazure C, Fleischmann RL, Hill CL, et al. The Yale-Brown obsessive compulsive scale. I. Development, use, and reliability. Arch Gen Psychiatry. I989;46:I006-IOII.

7. Jenkinson M, Smith S. A global optimisation method for robust affine registration of brain images. Med Image Anal. 200I;5:I43-I56.
8. Hawley JS, Weiner WJ. Hemiballismus: current concepts and review. Parkinsonism Relat Disord. 20I2;I8:I25-I29.

9. Baizabal-Carvallo JF, Jankovic J. Movement disorders induced by deep brain stimulation. Parkinsonism Relat Disord. 20I6;25:I-9.

Io. Sriram A, Foote KD, Oyama G, Kwak J, Zeilman PR, Okun MS. Brittle dyskinesia following STN but not GPi deep brain stimulation. Tremor Other Hyperkinet Mov (N Y). 20I4;4:242.

II. Zheng Z, Li Y, Li J, Zhang Y, Zhang X, Zhuang P. Stimulation-induced dyskinesia in the early stage after subthalamic deep brain stimulation. Stereotact Funct Neurosurg. 2010;88:29-34.

I2. Umemura A, Oka Y, Yamamoto K, Okita K, Matsukawa N, Yamada K. Complications of subthalamic nucleus stimulation in Parkinson's disease. Neurol Med Chir (Tokyo). 20II;5I:749-755.

13. Mallet L, Polosan M, Jaafari N, Baup N Welter ML, Fontaine D, et al. Subthalamic nucleus stimulation in severe obsessive-compulsive disorder. N Engl J Med. 2008;359:2I2I-2I34.

I4. Meissner W, Harnack D, Paul G, Reum T, Sohr R Morgenstern R, et al. Deep brain stimulation of subthalamic neurons increases striatal dopamine metabolism and induces contralateral circling in freely moving 6-hydroxydopamine-lesioned rats. Neurosci Lett. 2002;328:105-I08.

I5. Paul G, Reum T, Meissner W, Marburger A Sohr R, Morgenstern R, et al. High frequency stimulation of the subthalamic nucleus influences striatal dopaminergic metabolism in the naive rat. Neuroreport. 2000;II:44I-444.

I6. Karachi C, Grabli D, Baup N, Mounayar S, Tande D, Francois C, et al. Dysfunction of the subthalamic nucleus induces behavioral and movement disorders in monkeys. Mov Disord. 2009;24:II83-II92.

17. Richter EO, Hoque T, Halliday W, Lozano AM, Saint-Cyr JA. Determining the position and size of the subthalamic nucleus based on magnetic resonance imaging results in patients with advanced Parkinson disease. J Neurosurg. 2004;100: 54I-546.

I8. Plantinga BR, Temel Y, Duchin Y, Uludag K, Patriat R, Roebroeck A, et al. Individualized parcellation of the subthalamic nucleus in patients with Parkinson's disease with $7 \mathrm{~T}$ MRI [e-pub ahead of print]. Neuroimage. 2016. http://dx.doi. org/Io.IoI6/j.neuroimage.2016.09.023.

I9. Alexander GE, Crutcher MD. Functional architecture of basal ganglia circuits: neural substrates of parallel processing. Trends Neurosci. I990;I3: 266-27I.

20. Alexander GE, DeLong MR, Strick PL. Paralle organization of functionally segregated circuits linking basal ganglia and cortex. Annu Rev Neurosci. I986;9:357-38r.

2I. Lambert C, Zrinzo L, Nagy Z, Lutti A, Hariz M, Foltynie T, et al. Confirmation of functional zones 
within the human subthalamic nucleus: patterns of connectivity and sub-parcellation using diffusion weighted imaging. Neuroimage. 2012;60:83-94.

22. Percheron G, Filion M. Parallel processing in the basal ganglia: up to a point. Trends Neurosci. I99I; I4:55-59.

23. Joel D, Weiner I. The organization of the basal ganglia-thalamocortical circuits: open interconnected rather than closed segregated. Neuroscience. I994;63:363-379.
24. Janssen ML, Temel Y, Delaville C, Zwartjes DG Heida T, De Deurwaerdere P, et al. Cortico-subthalamic inputs from the motor, limbic, and associative areas in normal and dopaminedepleted rats are not fully segregated [e-pub ahead of print]. Brain Struct Funct. 2016. http://dx doi.org/I0.I007/s00429-0I6-I35I-5.

Written informed consent was obtained from the patient for publication of this case report and any accompanying images.
Conflict of interest statement: The authors declare that the article content was composed in the absence of any commercial or financial relationships that could be construed as a potential conflict of interest.

Received 9 February 2017; accepted 11 May 2017

Citation: World Neurosurg. (2017) 104:1048.e9-1048.e13 http://dx.doi.org/10.1016/j.wneu.2017.05.067

Journal homepage: www.WORLDNEUROSURGERY.org

Available online: www.sciencedirect.com

1878-8750/\$ - see front matter (C) 2017 Elsevier Inc. All rights reserved. 